\author{
Dr. I Gede Yusa, S.H., M.H., Prof. Dr. I Dewa Gede Atmadja,SH.MS, Prof. Dr. \\ I Made Arya Utama,SH.M.Hum, I Made Dedy Prianto,SH,M.Kn, Gede Prapta \\ Wiguna, SH., I Gede Tresna Pratama Wijaya, SH
}

\begin{abstract}
In general, the process made the deed by the notary is the presence of the parties to end the time of signing the deed be penghadap / the penghadap on consciousness itself and say the words as well as his desire before a notary who was then poured into the form of notarial deed according to the rules of law apply.

Sometimes the parties to come to a notary does not convey honest about the condition or the reason they mebuat deed, but on the other hand the notary does not have the authority to correct and as if acting as an investigator to determine materially what really happened, but can only be known with analysis of the notary itself before deciding to make a deed in accordance with the reasons submitted by the parties. Subjects are parties to the deed notary often also involve foreigners who are taking certain legal in the jurisdiction Repubik Indonesia. Legal actions of their choice instead of real defiance of the law in Indonesia, including the nominee agreement.

Seen in the provisions stipulated in the UUPA, that Article 2 (paragraph 1) determines that only Indonesian citizens who may have property rights. And of Article 42 UUPA is known that foreigners domiciled in Indonesia can have use rights. From this stems the agreement nominee, because on the one hand of strangers (foreigners) want to have a property that has obviously only be owned by Indonesia (citizen) and finally to secure the rights WNA is instituted Indonesian people who think they can provide a sense of security and has a certain closeness to borrow her name at the time they purchased the rights object on the ground, but all funds separately baliknamanya to purchase and process on behalf of the citizen borne by the WNA

This study is examining the legal normative legal materials associated with the manufacture deed nominee agreements and link it with the applicable law with regard to tenure rights to land that can be owned by foreigners menurutt land law rules applicable in Indonesia.

The choice of this legal act is certainly a violation of the law, in addition AGREEMENTS this nominee will be able to cause any harm to the parties as well as for third parties.
\end{abstract}

Keywords: Due to Law, Nominee, Third Party

\title{
ABSTRAK
}

Secara umum proses dibuatnya akta oleh notaris adalah atas kehadiran para pihak yang akhirnya saat penandatanganan akta menjadi penghadap/ para penghadap atas kesadaran sendiri dan mengutarakan maksudnya serta keinginannya dihadapan notaris yang kemudian dituangkan ke dalam bentuk akta Notaris sesuai aturan hukum berlaku.

Adakalanya para pihak yang datang ke notaris tidak menyampaikan secara jujur mengenai kondisi atau alasan mereka mebuat akta, akan tetapi disisi lain notaris tidak mempunyai kewenangan untuk mengoreksi dan seolah-olah bertindak sebagai seorang penyidik untuk mengetahui secara materiil apa yang sebenarnya terjadi, namun hanya dapat diketahui dengan analisa dari notaris itu sendiri sebelum memutuskan untuk membuat akta yang sesuai dengan alasan yang disampaikan oleh para pihak. Subjek yang menjadi pihak dalam pembuatan akta notaris seringkali pula melibatkan orang asing yang memang melakukan perbuatan hukum tertentu di wilayah hukum Repubik Indonesia. Perbuatan hukum yang menjadi pilihan mereka justru yang sebenarnya melanggar ketentuan yang berlaku di Indonesia, diantaranya perjanjian nominee.

Dilihat dalam ketentuan yang diatur dalam UUPA, bahwa Pasal 2 (ayat 1) menentukan bahwa hanya warga negara Indonesia yang dapat mempunyai hak milik. Dan dari Pasal 42 UUPA dapat diketahui bahwa orang asing yang berkedudukan di 
Indonesia dapat mempunyai hak pakai. Dari sinilah bermula terjadinya perjanjian nominee, karena di satu sisi orang asing (WNA) ingin mempunyai hak milik yang sudah jelas-jelas hanya bisa dimiliki oleh orang Indonesia (WNI) dan akhirnya untuk mengamankan hak-haknya WNA ini ditunjuklah orang Indonesia yang menurut mereka bisa memberikan rasa aman dan mempunyai kedekatan hubungan tertentu untuk dipinjam namanya pada saat mereka membeli objek hak atas tanah, akan tetapi seluruh dana utnuk pembelian maupun proses baliknamanya ke atas nama WNI ditanggung oleh si WNA

Penelitian ini merupakan penelitian hukum normatif yang meneliti bahan-bahan hukum terkait dengan pembuatan akta perjanjian nominee dan mengkaitkannya dengan aturan hukum yang berlaku berkenaan dengan penguasaan hak atas tanah yang dapat dimiliki oleh orang asing menurutt aturan hukum pertanahan yang berlaku di Indonesia.

Pilihan perbuatan hukum ini sudah tentu merupakan pelanggaran hukum, selain itu perjanian nominee ini akan dapat menimbulkan kerugian bagi para pihak maupun bagi pihak ketiga.

Kata Kunci : Akibat Hukum, Nominee, Pihak Ketiga

\section{AKIBAT HUKUM AKTA PERJANJIAN NOMINEE TERHADAP PIHAK KETIGA}

\section{A. Latar Belakang Masalah}

Hubungan internasional tampak terjadi setiap saat yang dapat kita saksikan dengan nyata, seperti WNA yang datang ke Indonesia atau WNI yang berpergian ke luar negeri. Perkawinan campuran antara warga negara Indonesia dengan pihak asing banyak terjadi. Demikian pula kematian seorang warga negara asing di Indonesia atau sebaliknya akan langsung ataupun tidak langsung akan menimbulkan permasalahan sendiri. Demikian pula halnya dengan perjanjian yang dibuat terkait dengan hubungan international sering dibuat orang WNI dan WNA.

Konsekwensi logis dari lalu lintas internasional ini adalah bertambah banyak terjadinya hubungan hukum berunsurkan asing diantara para individu, diantaranya di bidang hukum privat. Berkaitan dengan pengaturan hubungan ataupun perjanjian yang berlaku diantara para pihak inilah, notaris menjadi salah satu tempat yang dirasakan aman untuk mengatur hubungan hukum yang terjadi diantara mereka.

Notaris dalam membuat akta autentik adalah melakukan tindakan mengkonstatir apa yang dikehendaki oleh para pihak/penghadap untuk dinyatakan dalam akta yang dibuat dihadapannya, agar tidak melanggar undang-undang, sekaligus agar kehendak para pihak terlaksana secara baik dan benar, Fungsi keberadaan notaris didalam memberikan jasanya sekaligus agar tidak berbenturan maupun melanggar hukum, karena fungsi notaris adalah secara profesional terkait, sejauh kemampuannya untuk mencegah penyalahgunaan dari ketentuan hukum dan kesempatan yang diberikan oleh hukum.

Menurut Ismail Saleh, Notaris perlu memperhatikan empat hal pokok, yaitu

1. Dalam mejalankan tugas profesinya, seorang notaris harus mempunyai integritas moral yang mantap. Dalam hal ini, segala pertimbanganmoral harus melandasi pelaksanaan tugas profesinya. Walaupun akan memperoleh imbalan jasa yang tinggi, namun sesuatu yang bertentangan dengan moral yang baik harus dihindarkan ; 
2. Seorang notaris harus jujur, tidak hanya pada kliennya, juga pada dirinya sendiri. Ia harus mengetahui akan batas-batas kemampuannya, tidak memberi janjijanjisekedar untuk menyenangkan kliennya, atau agar si klien tetap mau memakai jasanya. Semua itu merupakan suatu ukuran tersendiri tentang kadar kejujuran intelektual seorang notaris;

3. Seorang notaris harus menyadari akan batas-batas kewenangannya. Ia harus mentaati ketentuan-ketentuan hukum yang berlaku tentang seberapa jauh ia dapat bertindak dan apa yang boleh serta apa yang tidak boleh dilakukan.

4. Sekalipun keahlian seseorang dapat dimanfaatkan sebagai upaya yang lugas untuk mendapatkan uang, namun dalam melaksanakan tugas profesinya ia tidak semata-mata didorong oleh pertimbangan uang. ${ }^{1}$

Salah satu pilihan perbuatan hukum yang menjadi pilihan khususnya Warga negara Asing yang berada di Indonesia adalah perjanjian nominee, yang sebenarnya merupakan suatu bentuk penyelundupan hukum atas aturan hukum pertanahan yang berlaku di Indonesia.

Akta Perjanjian Nominee yang dibuat para pihak di hadapan notaris pengaturannya secara khusus tidak ditemukan dalam sistem hukum Indonesia khususnya dalam hukum perjanjian Indonesia, dengan kata lain mengandung pengertian yang kosong/norma kosong, karena perjanjian nominee dapat dikatagorikakan sebagai penyelundupan hukum. Dengan adanya kekosongan pengaturan tersebut, maka salah satu permasalahannya adalah bagaimana akibat hukum yang ditimbulkan oleh perjanjian nominee terhadap pihak ketiga yang terkait dengan subtansi dari perjanjian itu sendiri. Berdasarkan hal itu, maka tujuan dari penelitian ini perlu dilakukan untuk mencegah lebih meluasnya pilihan perbuatan hukum para pihak dalam membuat Akta Perjanjian, sehingga perlu segera dilakukan pengaturannya secara tegas dalam sistem hukum di Indonesia. Oleh sebab itu sangat

${ }^{1}$ Salim H.S. dan Erlies Septiana Nurbani, 2013,Penerapan Teori Hukum Pada Penelitian Tesis dan Disertasi, Rajawali, Jakarta, hal. 17 menarik untuk meneliti mengenai AKIBAT HUKUM AKTA PERJANJIAN NOMINEE TERHADAP PIHAK KETIGA (DALAM PRAKTEKNYA DI KECAMATAN KUTA UTARA)

\section{B. Perumusan Masalah}

Berdasarkan pada pendahuluan, maka dalam penelitian ini dirumuskan permasalahan sebagai berikut :

1. Apa akibat hukumya terhadap pihak ketiga atas akta perjanjian yang didasarkan pada nominee?

2. Sejauh mana notaris dapat dituntut untuk bertanggungjawab atas kerugian yang timbul sebagai akibat dari Akta perjanjian yang didasarkan pada`nominee?

\section{B. PEMBAHASAN}

Mengenai syarat-syarat sahnya perjanjian dapat dikaji berdasarkan KUH Perdata (Civil Law) dan hukum kontrak Amerika. Dalam Hukum Eropa Continental syarat ini diatur dalam Pasal 1320 KUH Perdata mengemukakan bahwa, untuk sahnya suatu perjanjian diperlukan empat unsur yaitu :

a. Adanya kesepakatan kedua belah pihak. Kesepakatan adalah perseuaian persyaratan pernyataan kehendak antara satu orang atau lebih dengan pihak lainnya. Disini para pihak tidak hanya sepakat untuk mengikatkan diri, akan tetapi mencakup juga sepakat untuk mendapatkan prestasi. Dalam perjanjian timbal balik masingmasing pihak tidak saja mempunyai kewajiban, akan tetapi juga berhak atas prestasi yang telah dijanjikan

b. Kecakapan melakukan perbuatan hukum.

Kecakapan bertindak adalah kecakapan atau kemampuan untuk melakukan perbuatan hukum. Perbuatan hukum adalah perbuatan yang akan menimbulkan akibat hukum. Orang-orang yang akan mengadakan perjanjian haruslah orang-orang yang cakap 
dan mempunyai wewenang untuk melakukan perbuatan hukum. Anak yang baru dilahirkan bahkan anak yang masih ada dalam kandungan yang dari kacamata hukum dianggap sebagai telah lahir, berkedudukan sebagai subjek hukum. Sepanjang oleh hukum positif seseorang diakui sebagai subjek hukum, maka ia akan memiliki kewenangan hukum.

c. Adanya objek tertentu. Yang menjadi objek perjanjian adalah prestasi (pokok Pejanjian) Prestasi adalah apa yang menjadi kewajiban debitur dan apa yang menjadi hak kreditur. Prestasi terdiri dari :

1. Memberikan sesuatu

2. Berbuat sesuatu

3. Tidak berbuat sesuatu

(Pasal 1234 KUH Perdata)

d. Sebab yang halal.

Ketentuan pasal 1335 KUH Perdata menyebutkan bahwa Suatu perjanjian tanpa sebab atau yang telah dibuat karena sebab yang palsu atau terlarang, tidak mempunyai kekuatan (hukum). Dengan kata lain batal demi hukum. Kausa yang palsu dapat terjadi jika suatu kausa yang telah diuat tidak sesuai dengan keadaan yang sebenarnya atau kausa yang disimulasikan. Walaupun para pihak dapat membuat perjanjian apa saja, namun ada pengecualiannya yaitu sebuah perjanjian tidak boleh bertentangan dengan perundang-undangan ketertiban umum, moral dan kesusilaan.

Syarat a dan b merupakan syarat subyektif karena mengenai orang-orang atau subyek yang mengadakan perjanjian.Tidak terpenuhinya syarat subjektif dapat berakibat bahwa perjanjian tersebut dapat dibatalkan sedangkan syarat c dan d merupakan syarat objektif, dimana bila syarat objektif ini tidak terpenuhi maka perjanjian yang telah dibuat menjadi batal demi hukum.

Menurut Pasal 1 Peraturan Jabatan Notaris (Stbl.1860 Nomor 3) ditetapkan bahwa notaris adalah pejabat umum yang khusus berwenang membuat akta autentik mengenai semua perbuatan, persetujuan dan ketetapan yang diperintahkan oleh peraturan umum atau dikehendaki oleh yang berkepentingan, agar dengan surat outentik itu akan dinyatakan kepastian tentang tanggalnya, penyimpanan aktanya dan memberikan grosse, kutipan, dan salinannya, semuanya itu sejauh pembuatan akta-akta tersebut dan peraturan umum tidak juga ditugaskan atau disediakan untuk lain-lain pegawai atau orang lain. Sedangkan dalam Pasal 15 ayat 1 UU Nomor Pasal 15 ayat (1) UU Nomor 2 tahun 2014 menyebutkan : Notaris berwenang membuat akta autentik mengenai semua perbuatan, perjanjian dan ketetapan yang diharuskan oleh peraturan perundangundangan dan/atau yang dikehendaki oleh yang berkepentingan untuk dinyatakan dalam suatu akta autentik, menjamin kepastian tanggal pembuatan akta, menyimpan aktanya, memberikan grosse, Salinan dan kutipan akta, semuanya itu sepanjang akta-akta itu tidak juga ditugaskan atau dikecualikan kepada pejabat lain atau orang lain yang ditetapkan oleh undang-undang.

Dalam konstruksi Hukum Kenotariatan bahwa salah satu tugas jabatan notaris yaitu “ memformulasikan keinginan/tindakan penghadap/para penghadap kedalam 
bentuk akta otentik, dengan memperhatikan aturan hukum yang berlaku". Hal ini sebagaimana tersebut dalam Yurisprudensi Mahkamah Agung Republik Indonesia yang menyebutkan bahwa " ....Notaris fungsinya hanya mencatatkan/menuliskan apa-apa yang dikehendaki dan dikemukakan oleh para pihak yang menghadap notaris tersebut.Tidak ada kewajiban bagi notaris untuk menyelidiki secara materiil apa-apa (hal-hal) yang dikemukakan oleh penghadap di hadapan notaris tersebut" (Putusan Mahmakah Agung Nomor 702 k/Sip/1973, 5 September 1973.

Berdasarkan pada putusan Mahkamah Agung tersebut dapat disimpulkan bahwa :

1. Akta Notaris tidak dapat dibatalkan.

2. Fungsi Notaris hanya mencatatkan (menuliskan) apa-apa yang dikehendaki dan dikemukakan oleh para pihak yang menghadap Notaris tersebut.

3. Tidak ada kewajiban bagi Notaris untuk menyelidiki secara materil apa-apa( hal-hal) yang dikemukakan oleh penghadap tersebut.

Dengan bertambahnya tuntutan masyarakat akan pentingnya kekuatan pembuktian suatu akta, menuntut peranan notaris sebagai pejabat umum harus selalu dapat mengikuti perkembangan hukum dalam memberikan jasanya kepada masyarakat yang memerlukan dan menjaga akta-akta yang dibuatnya untuk selalu dapat memberikan kepastian hukum. Salah satu model perjanjian yang sering menajdi pilihan bagi orang asing yang sebenarnya ingin berinvestasi di Indonesia adalah Nominee

Dalam prakteknya sering terjadi berkenaan dengan orang asing yang melakukan tindakan hukum di Indonesia telah melakukan penyelundupan hukum, dengan melakukan pilihan hukum yang tidak didasarkan pada alasan yang sebenarnya, dengan kata lain mereka membuat akta yang didasarkan suatu peristiwa hukum yang tidak sebenarnya (simulasi). Adakalanya para pihak yang datang ke notaris tidak menyampaikan secara jujur mengenai kondisi atau alasan mereka membuat akta, akan tetapi disisi lain notaris tidak mempunyai kewenangan untuk mengoreksi secara materiil apa yang sebenarnya terjadi, dan hal ini hanya dapat diketahui dengan analisa dari notaris itu sendiri sebelum memutuskan untuk membuat akta yang sesuai dengan penjelasan yang disampaikan oleh para pihak.

Menurut Herlien Budiono, bentuk Perjanjian simulasi ada 2 yaitu :

a.Perjanjian Simulasi Absolut

Perjanjian simulasi absolut terjadi jika para pihak memperlihatkan dan memberi kesan kepada pihak ketiga bahwa telah terjadi suatu perbuatan hukum tertentu, padahal secara rahasia diperjannikan diantara para pihak bahwa sebenarnya tidak terjadi perubahan dari keadaan semula.

b. Perjanjian Simulasi Relatif

Perjanjian simulasi relatif terjadi jika oleh para pihak dibuat perjanjian yang sebenarnya ditujukan unutk memunculkan akibat hukumnya. Namun perjanjian itu dibuat mengikuti bentuk lain dari yang seharusnya dibuat. 
Dalam perjanjian silumasi relatif para pihak menginginkan perubahan keadaan atau perbuatan mereka tertuju pada akibat hukumnya. Artinya benar ada kehendak dan pernyataan yang tertuju pada membuat perjanjian dalam bentuk yang berbeda dari apa yang sebenarnya dari pernyataan timbal-balik diantara mereka berdua.

Berkaitan dengan terjadinya serta timbulnya perjanjian simulasi dalam prakteknya yang berkaitan dengan kepemilikan warga negara asing di Indonesia. Dalam Pasal 21 UUPA dinyatakan bahwa : (1) Hanya warga negara Indonesia dapat mempunyai hak milik. (2) Oleh Pemerintah ditetapkan badan-badan hukum yang dapat mempunyai hak milik dan syaratsyaratnya. (3) Orang asing yang sesudah berlakunya Undang-undang ini memperoleh hak milik karena pewarisan tanpa waktu atau percampuran harta karena perkawinan, demikian pula warga negara Indonesia yang mempunyai hak milik dan setelah berlakunya Undang-undang ini kehilangan kewarganegaraannya, wajib melepaskan hak itu didalam jangka waktu satu tahun sejak diperolehnya hak tersebut atau hilang kewarganegaraan itu. Jika sesudah jangka waktu tersebut lampau hak milik itu tidak dilepaskan, maka hak tersebut hapus karena hukum dan tanahnya jatuh kepada negara, dengan ketentuan bahwa hak-hak pihak lain yang membebaninya tetap berlangsung.

Dalam praktek pembuatan akta, kesepakatan para pihak untuk menentukan pilihan hukum, diawali dengan datangnya para pihak sebagai subjek hukum menghadap notaris. Notaris dalam menjalankan tugas jabatannya wajib berpedoman secara proaktif kepada aturan huum yang berkaitan dengan segala tindakan yang akan diambil untuk kemudian dituangkan dalam akta. Disisi lain notaris juga wajib meneliti semua berkas-berkas kelengkapan yang diserahkan dan ditunjukkan kepadanya serta mendengarkan keterangan atau pernyataan para pihak untuk kemudian dijadikan dasar dalam pembuata akta para pihak. Penegasan ini dapat dilihat dalam Pasal 16 ayat (1) huruf a UUJN yang antara lain menyarakan dalam menjalankan tugas jabatannya wajib bertindak seksama.

Berkenaan dengan permasalahan yang menjadi pokok dalam penelitian ini, perlu dipahami terlebih dahulu makna dari Perjanjian Nominee. Istilah nominee sering disamankan dengan istilah perwakilan atau pinjam nama, berdasarkan surat pernyataan atau surat kuasa yang dibuat oleh para pihak, dimana orang asing (WNA) meminjam nama orang Indonesia (WNI) untuk didaftarkan namanya sebagai pemegang hak atas tanah pada sertifikat yag menjadi objek dari perjanian nominee. Disisi lain para pihak membuat pernyataan yang isinya secara garis besar menyatakan bahwa yang sebenarnya mempunyai dana ataupun hak atas tanah tersebut adalah si WNA, dan si WNAlah yang mempunyai pengusaan serta menyimpan asli sertifikatnya. Kadangkala diantara mereka dibuat pilihan hukum bahwa si WNA menyewa selama jangka waktu yang cukup panjang, dengan tujuan agar 
memberikan ketenangan dan kenyamanan kepada si WNA. Kondisi ini kadang serba sulit untuk dihindari, karena di satu sisi pilihan-pilihan hukum yang ditentukan memang dimungkinkan.

Tahapan yang dilalui sebagai tindak lanjut dari perjanjian nominee ada beberapa tahap diantaranya :

1. Dibuat akta pengikatan dan kuasa lunas dari pemilik kepada WNI yang dipinjam namanya untuk nantinya didaftarkan dan sertifikat tercatat atas nama WNI yang bersangkutan

2. Dibuat akta yang bertujuan utnuk mengamankan si WNA yaitu akta pernyataan yang isinya penyatakan bahwa dalam transaksi poin nomor 1 diatas sebenarnya semua keuangan adalah milik dari si WNA, hanya si WNI dipinjam namanya, dan kadang dibuat perjanjian-perjanjian tambahan menurut kesepakatan mereka, dimana tidak jarang dalam perjanjian pelengkap itu ada memuat klausula bahwa si WNI akan mendapat kompensasi tertentu apabila nantinya si WNA akan menjual objek nominee.

3. Diteruskan dengan pembuatan akta jual beli PPAT setelah semua proses untuk itu dipenuhi, serta pendaftaran pada kantor pertanahan setempat untuk proses balik nama ke atas nama WNI.

Kalau disimak dari uraian di atas, terlihat bahwa terjadi penyelundupan hukum dalam menentukan pilihan perbuatan hukumnya, karena disatu sisi ketentuan Pasal 21 ayat (1) tentang hak milik yang menentukan bahwa hanya warga negara Indonesia yang dapat mempunyai hak miik, akan tetapi disisi lain pada saat yang bersamaan ada pihak WNA yang secara de facto sebenarnya mempunyai hak atas objek yang sama. Sesuai dengan ketentuan yang diatur dalam Pasal 41 sampai dengan Pasal 43 UUPA, dimana Pasal 41 UUPA menyatakan bahwa Hak Pakai adalah hak untuk menggunakan dan atau memungut hasil dari tanah yang dikuasai langsung oleh negara atau tanah milik orang lain, yang memberi wewenang dan kewajiban yang ditentukan dalam keputusan pemberiannya oleh pejabat yang berwenang memberikannya atau dalam perjanjian sewa menyewa atau perjanjian pengolahan tanah, segala sesuatu asal tidak bertentangan dengan jiwa dan ketentuan-ketentuan UUPA..

Lebih lanjut Pasal 42 menyebutkan bahwa yang dapat mempunyai Hak Pakai adalah :

1. Warga Neraga Indonesia;

2. Orang asing yang berkedudukan di Indonesia

3. Badan hukum yang didirikan menurut hukum Indonesia dan berkedudukan di Indonesia

4. Badan hukum asing yang mempunyai perwakilan di Indonesia Ketentuan lebih lanjut mengenai hak pakai diatur lebih lanjut dengandengan perundang-undangan, yaitu dalam PP Nomor 40 Tahun 1996,khususnya dalam Pasal 39 sampai dengan Paal 58, dimana mengenai subjek dari hak pakai menurut Pasal 30 PP Nomor 40 Tahun 1996 adalah :

\section{Warga Negara Indonesia}


2. Badan hukum yang didirikan oleh hukum Indonesia dan berkedudukan di Indonesia

3. Departemen, Lembaga Pemerintah Non Departemen dan Pemerintah Daerah

4. Badan-badan keagamaan dan sosial

5. Orang asing yang berkedudukan di Indonesia

6. Badan hukum asing yang mempunyai perwakilan di Indonesia

7. Perwakilan negara asing dan perwakilan badan internasional.

Jadi dalam UUPA maupun dalam PP 40 tahun 1996 jelas disebutkan bahwa untuk orang asing berhak atas Hak Pakai tapi bukan hak milik. Orang asing cenderung dan mempunyai keinginann untuk mempunyai hak atas tanah dengan status hak milik, karena mereka tahu bahwa hak milik merupakan hak yang terkuat dan terpenuh serta tidak ada masa berlakunya, dengan pengecualian tertentu. Hal inilah yang menjadi alasan para pihak memilih jalan pintas dengan keinginan untuk mengamankan dan menguatkan hak-hak pemilik sebenarnya (WNA) atas objek tersebut.Pilihan hukum ini merupakan tindakan penyamaran yang sebenarnya merupakan penyelundupan hukum meskipun itu merupakan kehendak para pihak. "Kehendak" dimaksudkan sebagai kehendak yang dinyatakan dan ditujukan untuk timbulnya akibat hukum. Pada umumnya pernyataan yang diberikan seseorang adalah sesuai dengan kehendak. Namun juga terbuka kemungkinan ada ketidak sesuaian antara kehendak dan pernyataan.
Menurut Herlien Budiono ini terjadi dalam 3 hal yaitu ${ }^{2}$

1. Pernyataan (sebenarnya) tidak diinginkan

2. Pernyataan betul diinginkan, tetapi tidak dalam arti yang sebagai yang diterima (ditafsirkan)pihak lawan dan;

3. Pernyataan diinginkan sesuai dengan yang dimaksud oleh pihak lawan, tetapi akibat hukumnya tidak dikehendaki.

Dilihat dari ketiga hal di atas, dapat dikatakan bahwa perjanjian nominee, yang pada dasarnya merupakan penyelundupan hukum dan bukan merupakan perjanjian yang sebenarnya (simulasi), karena disini memang merupakan penyimpangan dari maksud tujuan menimbulkan akibat hukum. Penyimpangan terhadap :kepercayaan yang tercapai" telah dilakukan antara para pihak untuk secara diam-diam dan secara sadar melakukan tindakan hukum tertentu yang menyimpang dari apa yang seharusnya terjadi. Dapat dikatakan disini bahwa pihak-pihak melakukan "persengkokolan" atau terjadi tindakan hukum pura-pura.

Dalam praktek di Kuta Utara ada beberapa alasan yang dipergunakan oleh WNA mengapa mereka lebih memilih perjanjian nominee, padahal UUPA maupun PP nomor 40 tahun 1996 telah memberikan payung hukum untuk mereka pilih sehingga mereka dapat menjadi pemegang hak yang sah atas objek yang mereka kehendaki sepanjang persyaratan baik subjektif maupun objektifnya mereka penuhi. Diantaranya adalah :

2 Herlien Budiono, 2009, Ajaran Umum Hukum Perjanjian dan penerapannya di Bidang kenotariatan, PT Citra Aditya Bhakti, Bandung hal. 78-79. 
1. Berdasarkan informasi dan pengetahuan mereka bahwa tanah dengan status hak milik paling aman untuk dimiliki. Padahal sifat aman ini diberikan kepada mereka yang namanya tercatat di sertifikat hak atas tanah bersangkutan yang ada pada kantor pertanahan setempat bukan kepada WNA yang justru mengeluarkan sejumlah dana untuk pembelian objek hak atas tanah tersebut.

2. Mereka mempunyai hubungan tertentu dengan seorang WNI yang saat itu mereka sangat percaya untuk namanya dipinjam dalam proses jual beli objek hak atas tanah, meskipun sebenarnya semua dananya berasal dari orang asing

3. Mereka mempunyai ketakutan akan adanya perubahan aturan hukum yang berlaku saat mereka telah membeli tanah dan nama orang asing tersebut telah terdaftar dan tercantum dalam sertfikat hak pakainya, sehingga justru mereka dalam ketidakpastian. Secara garis besar mereka kerasa tidak mendapat kepastian hukum apabila mereka memilih hak pakai.

4. Dari banyak pihak yang telah memilih perjanjian nominee, belum ada yang memperoleh masalah, sehingga rekan-rekan mereka merasa dapat secara aman dan nyaman dengan prjanjian nominee. Sebagai alas hak yang memberi mereka kekuatan adalah adanya pernyataan yang menyatakan bahwa si WNI sebenanya hanya dipinjam namanya dalam pembelian hak atas tanah, sedangkan secara de facto ha $\mathrm{k}$ atas tanah tersebut adalah milik si WNA. Dan perjanjian tersebut telah dibuat di notaris yang menurut mereka tempat berlindung hukum yang aman. Padahal dari segi akibat hukum, apabila disadari pilihan ini akan membawa konsewensi bahwa kerugian yang besar bagi para pihak maupun pihak ketiga.

5. Perhitungan biaya yang harus mereka keluarkan setiap akan melakukan perpanjangan hak pakai juga menjadi alasan mengapa mereka memiih perjanjian nominee Perjanjian simulasi dapat saja menimbulkan kerugian bagi pihak ketiga Dalam perjanjian nominee, dapat dilihat adanya unsur-unsur :

1. Adanya perjanjian pemberian kuasa dari si WNA kepada si WNI, dimana beneficial owner sebagai pemberi kuasa dan nominee sebagai penerima kuasa yang didasarkan pada adanya kepercayaan dan beneficial owner kepada nominee;

2. Kuasa yang diberikan bersifat khusus dengan jenis tindakan hukum yang terbatas;

3. Disini nominee (WNI) bertindak seolah-olah sebagai wakil dari beneficial owner didepan hukum.

Berkaitan dengan akibat hukum yang ditimbulkan dari akta Perjanian nominee yang dapat digolongkan pada perjanjian simulasi terhadap pihak ketiga, ini memiliki pengaruh terhadap pihak ketiga. Pengaruh tersebut dilatar belakangi pada jenis simulasi yang diperbuat :

a. Pada simulasi absolut (mutlak) pihak ketiga tetap mengacu kepada perjanjian yang dilakukan adalah 
semu sehingga keadaan hukum yang seharusnya diterimanya akan tetap pada keadaan semula. Contoh : Jual beli yang dilakukan orang yang hampir pailit untuk menghindari penyitaan. Pihak ketiga dapat bertahan bahwa perjanjian tersebut adalah semu sehingga peralihan hak atas barang tidak dilakukan kepada teman kepercayaannya dan konsekuensi hukum bagi pihak ketiga akan tetap pada keadaan semula seperti tidak adanya perjanjian tersebut.

b.Pada simulasi relatif, bagi pihak ketiga terbuka tiga kemungkinan:

1) Bagi pihak ketiga yang melihat perjanjian terbatas pada perjanjian yang disimulasikan, maka akan dilindungi terhadap janji-janji yang tersembunyi. Pasal 1873 KUHPerdata mengatur bahwa: perjanjian-perjanjian menyusul yang diadakan dengan akta/perbuatan tersendiri yang bertentangan dengan perjanjian semula hanya mempunyai kekuatan bukti bagi pihak-pihak yang menjadi peserta dalam akta tersebut besarta ahli waris atau yang memperoleh hak, tetapi tidak mempunyai kekuatan hukum terhadap pihak ketiga.

2) Pihak ketiga yang mengetahui sejak awal atau kemudian maka terhadapnya sebagaimana diatur di dalam ketentuan dalam 1873 KUHPerdata, yang menentukan bahwa :Persetujuan-persetujuan lebih lanjut yang dibuat dalam suatu akta tersendiri (dimaksudkan disini perjanjian simulasi) yang bertentangan dengan akta asli, hanya memberikan bukti diantara pihak yang turut serta dan para ahli warisnya (orang yang mendapat hak daripada mereka, tetapi tidak dapat berlaku terhadap orangorang pihak ketiga).

3) Pihak ketiga yang mengetahui seluruh manipulasi/tipu daya para pihak, dapat menyatakan: 1) Bahwa perjanjian semu sebagai perjanjian yang tidak dikehendaki para pihak-pihak tidak mempunyai kekuatan hukum dan 2) Bahwa perjanjian yang disimulasikan itu memang dikehendaki terbukti

Baik perjanjian simulasi terutama perjanjian simulasi absolute digolongkan sebagai perjanjian yang causanya tidak halal, dengan kata lain dibuat dengan dasar sebab yang palsu. Dengan demikian pihak ketiga, baik dalam perjanjian simulasi absolut maupun yang relatif, tiak terikat pada apa yang dijanjikan dalam perjanjian simulasi.Namun, ini hanya berlaku sepanjang pihak ketiga secara itikad baik tidak mengetahui adanya perjanjian simulasi tersebut. Dan karena itu pihak ketiga itu

Bila dilihat dari alasan yang mendasari dibuatnya Akta Perjanjian Nominee, dapat dikatakan bahwa akta perjanjian itu merupakan pelaksanaan perjanjian yang terlarang. Maksud dan tujuan membuat perjanjian yang dilarang adalah perjanjian yang sengaja dibuat untuk menyelundupi undangundang atau menghindari ketentuan undang-undang 
Berdasarkan pada apa yang
diuraikan diatas, maka atas permasalahan-permasalahan tersebut dapat disimpulkan bahwa :

1. Akta Perjanjian Nominee yang didasarkan pada perjanjian simulasi absolut maupun yang relatif, maka pihak ketiga tidak terikat pada apa yang dijanjikan dalam Akta perjanjian tersebut. Namun, ini hanya berlaku sepanjang pihak ketiga secara itikad baik tidak mengetahui adanya Akta perjanjian tersebut. Dan karena itu pihak ketiga itu mendapat perlindungan hukum
2. Notaris, dapat dikenai sanki berupa sanksi perdata, administrasi dan kode etik, maupun sanksi pidana atas akibat hukum yang ditimbulkan dari akta perjanjian nominee yang dibuatnya, sepanjang unsur-unsur untuk penjatuhan sanksi tersebut terpenuhi.

Melihat hasil penelitian yang diperoleh, melalui artikel ini perlu kiranya disarankan terutama kepada Warga Negara Asing untuk mencegah terjadinya penyelundupan hukum, maka sebaiknya mereka memenuhi aturan yang berlaku bagi pnguasaan tanah oleh orang asing sehingga dapat dicegah akibat hukum yang tidak diinginkan.

\section{DAFTAR PUSTAKA}

Andasasmita, Komar., 1990, Notaris II (Contoh Akta otentik dan Penjelasannya), Ikatan Notaris Indonesia Daerah Jawa Barat, Bandung

Alie, Zainuddin.H., 2009, Metode Penelitian Hukum, Sinar Grafika, Jakarta

Ajie, Habib,2008, Hukum Notaris Indonesia (Tafsir Tematik terhadap UU No. 30 Tahun 2004 tentang Jabatan Notaris).

Bahctiar Herlina Suyati, 2008, Contoh Akta Notaris Dan Akta Di Bawah Tangan Cv. Mandar Maju, Bandung

Bachtiar Herlina Suyati, 2002., Contoh Akta Notaris Dan Akta Di Bawah Tangan, $\mathrm{Cv}$.Mandar Maju, Bandung

Budiono Herlien, 2015, Kumpulan Tulisan Hukum Perdata (Di Bidang Kenotariatan), PT Citra Aditya Bakti, Bandung,

Boediono, Herlien, 2009, Ajaran Umum Hukum Perjanjian dan Penerapannya di Bidang Kenotariatan, PT.Citra Aditya Bakti. Bandung,

Chomzah., Achmad 2004, Hukum Agraria, Prestasi Pustaka Publisher, Jakarta

Gandasubrata Purwoto.S., Himpunan Surat Edaran Mahkamah Agung., Mahkamah Agung RI, Jakarta,

Gunardi dan Markus Gunawan, Kitab Undang-Undang Hukum Kenotariatan (Himpunan Peraturan tentang Kenotariatan), 2007, PT Raja Grafindo Persada, Jakarta

Hadjoen Philipus M dan Sri Djamiati Tatiek,2005, Argumentasi Hukum, Gadjah Mada University Press, Surabaya,

Handoko Widhi, 2014, Kebijakan Hukum Pertanahan (Sebuah Refleksi Keadilan Hukum Progresif), Thafa Medica, Semarang.

Joses Sembiring, Jimmy, 2009, Legal Officer, Transmedia Pustaka, Jakarta.

Joko Subagyo,P., 1999, Metode Penelitian DalamTeori dan Praktek, Cet III, Rineka Cipta, Jakarta,

Peter Alderson., 1995., Legal Dictionary For Australians., Auatralia, Mr Graw-Hill Book Company.

Salim,H.S., 2003, Perkembangan Hukum Kontrak Innominat, Jakarta, Sinar Grafika, Jakarta,

Sjafurrachman, 2011, Aspek Pertanggungjawaban Notaris Dalam Pembuatan Akta, Mandar Maju, Bandung.

Santosa, Urip., 2005, Hukum Agraria dan Hak-Hak Atas Tanah, Fajar Interpratama Offset, Jakarta

Sodiki, Achmad., 2013, Politik Hukum Agraria, Konstitusi Konpress, Jakarta 
Subekti, R., 2001, Hukum Pembuktian, Pradnya Paramita, Jakarta

Undang-Undang Nomor 30 tahun 2004 tentang Jabatan Notaris

Undang-Undang Nomor 5 Tahun 1960 tentang UUPA

Peraturan Pemerintah Nomor 24 tahun 1997 tentang Pendaftaran Tanah 